\title{
PENINGKATAN HASIL BELAJAR MATEMATIKA MELALUI MEDIA TABEL DENGAN POWER POINT PADA SISWA SEKOLAH DASAR
}

\section{Retno Sapartien}

SDN Bonangrejo Bonang Demak

Jawa Tengah, Indonesia

\section{Info Artikel}

Sejarah Artikel:

Diterima Agustus 2016

Disetujui November 2016

Dipublikasikan Desember 2016

\section{Keywords:}

Hasil Belajar Matematika,

Media Tabel dengan Power

Point

\begin{abstract}
The purpose of this study was to determine the effectiveness of the use of media "Table" with Power Point in mathematics learning material determine the greatest common factor and least common multiple in improving learning outcomes of learners and to determine changes in learning behavior. Using the method of action research consisted of two cycles and each cycle to follow the stages of planning, implementation of the action, observations, and reflection with data collection using observation, testing, and documentation. The results of the study in cycle 1 the average value of 76 students, with 19 students completed and there are 6 learners unfinished. While on the second cycle of the average value increased to 88 to 22 students completed and 3 learners still unresolved. Utilization of media tables in love with the variation application PowerPoint more effectively to instill the concept of how to determine the FPB and the Commission in learning mathematics in fourth grade elementary school Bonangrejo first half of the school year 2015/2016.
\end{abstract}

\begin{abstract}
Abstrak
Tujuan penelitian ini adalah untuk mengetahui efektifitas pemanfaatan media "Tabel" dengan Power Point dalam pembelajaran matematika materi menentukan faktor persekutuan terbesar dan kelipatan persekutuan terkecil dalam meningkatkan hasil belajar peserta didik serta untuk mengetahui perubahan perilaku dalam pembelajaran. Menggunakan metode penelitian tindakan kelas terdiri dari dua siklus dan masing-masing siklus mengikuti tahapan perencanaan (planning) pelaksanaan tindakan (action), pengamatan (observation) dan refleksi (reflecting) dengan teknik pengumpulan data menggunakan cara observasi, tes, dan dokumentasi. Hasil penelitian pada siklus 1 rata-rata nilai peserta didik 76, dengan 19 peserta didik tuntas dan masih ada 6 peserta didik yang belum tuntas. Sedangkan pada siklus 2 rata-rata nilai meningkat menjadi 88 dengan 22 peserta didik tuntas dan 3 peserta didik masih belum tuntas. Pemanfaatan media tabel cinta dengan variasi aplikasi Power Point lebih efektif untuk menanamkan konsep cara menentukan FPB dan KPK dalam pembelajaran Matematika di kelas IV SD Negeri Bonangrejo semester 1 tahun pelajaran 2015/2016
\end{abstract}

(C) 2016 Universitas Muria Kudus
p-ISSN 2087-9385

e-ISSN 2528-696X

Program Studi Pendidikan Guru Sekolah Dasar

Fakultas Keguruan dan Ilmu Pendidikan Universitas Muria Kudus

Kampus UMK Gondangmanis, Bae Kudus Gd. L. It I PO. BOX 53

Kudus

Tlp (0291) 438229 ex.147 Fax. (0291) 437198

E-mail: retno.sapartien@gmail.com 


\section{PENDAHULUAN}

Pembelajaran di Sekolah Dasar akan lebih efektif, kreatif, dan menyenangkan apabila memanfaatkan berbagai media dan metode secara bervariasi. Pembelajaran yang bervariasi bertujuan agar menimbulkan minat dan motivasi belajar peserta didik terhadap semua mata pelajaran di sekolah. Namun demikian kenyataan di lapangan menunjukkan bahwa kegiatan pembelajaran di sekolah dasar, berdasarkan pengamatan penulis dan informasi dari berbagai pihak, masih bersifat konvensional. Metode yang digunakan guru dalam pembelajaran masih cenderung pada metode ceramah, dan kurang memanfaatkan media. Sehingga peserta didik menelaah konsep secara abstrak sehingga mudah terlupakan. Apalagi pada pelajaran Matematika, bila peserta didik tidak memahami konsep awal suatu pengerjaan, maka akan kesulitann dalam menghadapi soal-soal lainnya yang lebih kompleks. Akibatnya peserta didik malas dan tidak tertarik terhadap pelajaran Matematika.

Pembelajaran di sekolah dasar yang kurang menarik memang akan membosankan peserta didik. Selain itu, hasil belajar peserta didik juga belum sesuai dengan tujuan yang diharapan. Hal ini dapat dilihat dari kegiatan pembelajaran Matematika semester gasal tahun pelajaran 2015/2016 kelas IV Sekolah Dasar Negeri Bonangrejo pada materi "Menentukan faktor persekutuan terbesar dan kelipatan persekutuan terkecil". Pada kegiatan pembelajaran yang dilakukan dengan metode ceramah ini ternyata hasil belajar peserta didik yang mencapai KKM (Kriteria Kelulusan Minimal) yang ditentukan sekolah yaitu 65 , hanya 8 peserta didik (32\%) dari jumlah peserta didik sebanyak 25 peserta didik. Sedangkan 17 peserta didik (68\%) masih tidak mencapai KKM yang ditentukan.

Rendahnya hasil belajar peserta didik dalam materi menentukan FPB (Faktor Persekutuan Terbesar) dan KPK (Kelipatan Persekutuan Terkecil) ini berdasarkan analisis dan pengamatan guru kelas, ternyata karena peserta didik kurang menguasai konsep awal cara mencari FPB dan KPK. Padahal apabila peserta didik tidak menguasai konsep awal dalam menentukan FPB dan KPK, maka peserta didik akan senantiasa mengalami kesulitan untuk mengerjakan soal-soal yang berhubungan dengan FPB dan KPK, apalagi dalam bentuk soal cerita. Hal ini karena konsep pembelajaran Matematika merupakan materi yang berkesinambungan untuk pembelajaran selanjutnya.

Berdasarkan kondisi di atas, guru kelas dengan mendapatkan masukan serta informasi dari berbagai pihak menentukan strategi baru untuk mengadakan pembelajaran dengan memanfaatkan media. Media yang dipilih dalam hal ini adalah: papan magnetik, kartu bilangan yang melambangkan simbol cinta sehingga diberi nama "Media Tabel". Serta aplikasi Microsoft Power Point, yang digunakan untuk mengecek hasil pekerjaan peserta didik sudah benar atau belum pada waktu bermain tabel cinta, dan ketika peserta didik telah selesai mengerjakan soal latihan sebelum waktu pembahasan tiba. Pembelajaran dengan "Media Tabel" dengan variasi aplikasi Mokrosoft Powerpoint ini merupakan upaya untuk mengatasi permasalahan rendahnya nilai peserta didik dalam pembelajaran Matematika bagi peserta didik kelas empat Sekolah Dasar, khususnya materi yang berhubungan dengan Faktor Persekutuan Terbesar dan Kelipatan Persekutuan Terkecil. Adapun langkah-langkah dalam metode bermain ini adalah: 1) Guru dan peserta didik menyediakan media papan magnetik, kartu bilangan di bekas tempat disket, serta kartu bilangan yang didesain dengan bentuk lambang cinta, kartu soal-soal yang berkaitan dengan FPB dan KPK, 2) Peserta didik mempraktikkan bermain dengan kelompoknya yaitu: satu peserta didik membaca soal, peserta didik kedua menempelkan kartu bilangan pada tabel papan magnetik sesuai dengan soal yang dibacakan, peserta didik ketiga memberi tanda pada deretan tabel untuk mempermudah cara mencari FPB atau KPK, peserta didik keempat menghitung FPB atau KPK berdasarkan pada tabel. Peserta didik kelima mencocokkan jawaban temannya dengan menggunakan program power point di komputer yang tersedia. Apabila jawaban benar maka kelompok tersebut menerima kupon yang dapat ditukarkan es cream mini cornetto pada waktu pelajaran selesai, dan apabila jawaban salah maka semua anggota kelompok menyanyikan lagu yang diminta oleh peserta didik kelompok lainnya 3) Setelah selesai bermain, peserta didik mengerjakan latihan. Peserta didik yang sudah selesai mengerjakan latihan sebelum waktu pembahasan, dapat mencocokkan hasil pekerjaannya dengan menggunakan komputer/laptop, bila jawaban peserta didik salah maka peserta didik mengulangi mengerjakan latihan, 4) Pembahasan secara klasikal, dan 5) ulangan formatif.

Tujuan penelitian ini adalah untuk mengetahui efektifitas pemanfaatan media "Tabel" dengan Power Point dalam pembelajaran matematika materi menentukan faktor persekutuan terbesar dan kelipatan persekutuan terkecil dalam meningkatkan hasil belajar peserta didik. Selain itu untuk mengetahui perubahan perilaku dalam pembelajaran setelah diadakan 
perbaikan pembelajaran menggunakan metode tersebut.

\section{METODE}

Penelitian dilakukan di kelas IV SD Negeri Bonangrejo Kecamatan Bonang. Penelitian dilakukan dua siklus, tiap-tiap siklus sebanyak dua kali pertemuan. Siklus pertama dilakukan pada hari Kamis 6 Agustus 2015 dan siklus ke 2 dilakukan pada hari Kamis 20 Agustus 2015. Subjek penelitian adalah peserta didik kelas IV SD Negeri Bonangrejo yang jumlahnya sebanyak 25 peserta didik, terdiri atas 6 peserta didik berjenis kelamin perempuan dan 19 peserta didik berjenis kelamin laki-laki. Fokus pembelajaran pada materi Menetukan FPB dan KPK. Adapun aplikasi pemanfaatan media media tabel dengan variasi microsoft power point.

Metodologi yang digunakan dalam peneletian ini menggunakan prosedur penelitian tindakan kelas, sebagai perbaikan pembelajaran berdasarkan permasalahan yang dijumpai di kelas. Penelitian ini menggunakan pendekatan kualitatif dengan pemaparan menggunakan metode deskriptif. Pelaksanan dalam penelitian tindakan kelas dilaksanakan secara simultan (siklus). Siklus yang akan dipergunakan dalam penelitian ini ada dua siklus dan masing-masing siklus mengikuti tahapan perencanaan (planning) pelaksanaan tindakan (action), pengamatan (observation) dan refleksi (reflecting).

Teknik pengumpulan data dalam penelitian ini menggunakan beberapa cara yaitu: observasi, tes, dan dokumentasi. Observasi digunakan untuk mengumpulkan data pelaksanaan penelitian setiap siklus. Tes digunakan untuk mengumpulkan data hasil belajar siswa pada akhir kegiatan setiap siklus dengan memberikan sejumlah soal tes kepada subjek penelitian. Dokumentesi digunakan untuk mengumpulkan data dalam bentuk dokumen-dokumen baik dokumen tertulis, gambar maupun elektronik.

\section{HASIL DAN PEMBAHASAN}

\section{Hasil Prasiklus}

Hasil pengamatan awal /prasiklus menunjukkan masih banyak peserta didik yang belum menguasai materi FPB dan KPK. Peserta didik yang belum dapat mencapai kriteria ketuntasan minimal (70) sebanyak 17 peserta didik atau $68 \%$ dari jumlah peserta didik seluruhnya 25. Sedangkann peserta didik yang mencapai tingkat ketuntasan minimal sebanyak 8 peserta didik atau sebanyak $32 \%$ dari jumlah peserta didik seluruhnya.

\section{Hasil Siklus I}

Hasil yang diperoleh dari pelaksanaan siklus I ini sudah mengalami peningkatan yang cukup signifikan. Hal ini ditunjukan dari 25 peserta didik, sebanyak 18 peserta didik (72\%) mencapai ketuntasan dalam pembelajaran matematika materi menentukan FPB dan KPK, dan 7 peserta didik atau $28 \%$ peserta didik yang belum tuntas. Apabila dipaparkan secara rinci sebagai berikut: peserta didik yang mendapatkan nilai 50 sebanyak 2 peserta didik atau sekitar $8 \%$. Peserta didik yang memperoleh nilai 60 sebanyak 5 peserta didik atau 20\%. Peserta didik yang memperoleh nilai dibatas KKM dengan nilai 70 sebanyak 10 peserta didik atau 40\%. Sedangkan peserta didik yang memperoleh hasil belajar di atas nilai $\mathrm{KKm}$ terdiri dari 5 peserta didik mendapatkan nilai 80 atau 20\%. Peserta didik yang mencapai nilai 90 hanya 2 peserta didik atau $8 \%$, dan hanya 1 peserta didik yang mendapatkan nilai 100 atau $4 \%$.

\section{Hasil Siklus II}

Hasil yang diperoleh dari pembelajaran siklus II yaitu sebanyak 1 peserta didik yang mendapatkan nilai 50 atau 4\%. Peserta didik yang mendapatkan nilai 60 sebanyak 2 peserta didik atau $8 \%$. Sebanyak 4 peserta didik mendapatkan nilai di batas KKM (70) atau sebanyak $16 \%$. Peserta didik yang mendapatkan nilai 80 sebanyak 6 atau 24\%. Peserta didik yang mendapatkan nilai 90 sebanyak 7 peserta didik atau sebanyak 28\%. Sedangkan peserta didik yang mecapai nilai maksimal yaitu 100 sebanyak 5 peserta didik atau sebanyak $20 \%$. Hasil pada siklus II tersebut, menunjukan dari 25 peserta didik yang tuntas KKM sebanyak 22 peserta didik atau sekitar $88 \%$, dan peserta didik yang belum tuntas masih 3 peserta didik atau sekitar $12 \%$. Secara keseluruhan pembelajaran perkembangan kemampuan pemahaman FPB dan KPK peserta didik kelas IV SD Negeri Bonangrejo mengalami peningkatan.

\section{Pembahasan}

Pembelajaran dengan memanfaatkan media tabel dengan variasi aplikasi microsoft power point di kelas IV SD Negeri Bonangrejo, dengan materi pembelajaran sifat-sifat operasi hitung campuran termasuk campuran FPB dan KPK, dengan pokok materi "Menentukan KPK dan FPB", menunjukkan hasil belajar yang lebih efektif. Bertolak dari perkembangan nilai peserta didik yang telah dijabarkan di atas dapat dikatakan bahwa ada perbedaan yang signifikan dari prestasi belajar peserta didik antara kegiatan pembelajaran yang dilakukan sebelumnya yaitu 
pembelajaran dengan menggunakan metode ceramah, dengan pembelajaran setelah menggunakan tindakan (pemanfaatan media tabel dengan variasi aplikasi microsoft power point dalam pembelajaran Matematika di kelas IV SD Negeri Bonangrejo ) pada siklus I dan II.

Hasil penelitian ini menyatakan bahwa dalam pemanfaatan media tabel dengan variasi aplikasi microsoft power point dalam pembelajaran Matematika kelas IV semester 1 di SD Negeri Bonangrejo tahun pelajaran 2015/2016, khususnya pada stándar kompetensi menggunakan sifat-sifat operasi hitung campuran termasuk campuran FPB dan KPK, dengan pokok materi "Menentukan KPK dan FPB", menunjukkan hasil belajar peserta didik yang meningkat. Melalui perbandingan nilai rata-rata, pada nilai sebelum tindakan, siklus I dan siklus ke II, yaitu 55,9 , 74.4 dan 85 dapat ditentukan pula bahwa pembelajaran ini bernilai positif, artinya dengan memanfaatkan media tabel dengan variasi aplikasi microsoft power point, dapat dijadikan sarana efektif untuk menanamkan konsep cara menentukan FPB dan KPK dalam pembelajaran Matematika di kelas IV SD Negeri Bonangrejo.

Pemanfaatan media tabel dengan variasi aplikasi microsoft power point, dalam pembelajaran Matematika yang dilakukan, terlihat bahwa peserta didik belajar dengan antusias dan semangat, sehingga konsep mencari FPB dan KPK yang ditanamkan mencapai sasaran. Melalui penguasaan konsep tentang cara menentukan FPB dan KPK, maka peserta didik dapat memecahkan soal cerita yang berhubungan dengan hubungan materi FPB dan KPK.

Dengan pemanfaatan media ini, ternyata dapat menarik perhatian peserta didik. Mendengar kata cinta dan memainkan lambang-lambang cinta dalam kartu bilangan, ternyata menarik minat dan semangat belajar peserta didik. Peserta didik yang biasanya kurang perhatiannya, tampak menjadi lebih antusias pada pembelajaran ini. Demikian pula peserta didik yang sudah mulai jenuh dengan pembelajaran yang monoton dan tidak bervariasi, kembali lebih berkonsentrasi pada pembelajaran melalui pembelajaran dengan media tabel dengan variasi aplikasi microsoft power point. Hal ini senada dengan manfaat dari penggunaan media pembelajaran menurut Hamalik (1994 : 108) antara lain adalah : (1) menarik minat; (2) memberi gambaran yang jelas; (3) mempunyai tinjauan yang luas; dan (4) mendorong kreativitas peserta didik.

Berkaitan dengan pendapat tersebut, maka pemanfaatan media dengan media tabel dengan variasi aplikasi microsoft power point memang dapat menarik minat peserta didik untuk belajar dan memahami konsep menentukan FPB dan
KPK, sehingga peserta didik mempunyai tinjauan yang luas dalam menyelesaikan masalah mulai dari permasalahan yang mudah dan sederhana hingga yang kompleks, misalnya dari soal Matematika biasa yang hanya sebatas mencari FPB dan KPK , menjadi soal Matematika yang lebih kompleks dalam bentuk soal cerita.

Dengan adanya keuntungan-keuntungan dari pemanfaatan media dengan media tabel dengan variasi aplikasi microsoft power point ini, maka akhirnya hipotesis yang dikemukakan diterima, yakni pembelajaran dengan memanfaatkan media tabel dengan variasi aplikasi microsoft power point terbukti dapat meningkatkan prestasi belajar peserta didik dalam pembelajaran Matematika materi menentukan FPB dan KPK di kelas IV SD Negeri Bonangrejo, semester gasal tahun pelajaran 2015/2016.

Ada beberapa faktor yang mempengaruhi keberhasilan dalam pembelajaran dengan memanfaatkan media dengan media media tabel dengan variasi aplikasi microsoft power point dalam pembelajaran, antara lain: (1) kesanggupan guru untuk memanfaatkan media yang bervariasi; (2) pengusaan guru pada materi, metode, dan media yang dipilihnya, cara menyampaikan guru kepada peserta didik; (3) pengelolaan kelas yang efektif; (4) cara pembahasan hasil kegiatan peserta didik; dan (5) tindak lanjut dari kegiatan yang dilaksanakan guru. Apabila faktor-faktor itu dapat diperhatikan oleh guru, maka kegiatan akan mencapai tujuan yang maksimal

\section{SIMPULAN}

Pembelajaran Matematika materi menentukan FPB dan KPK lebih efektif dan meningkatnya prestasi belajar peserta didik melalui penerapan media tabel dengan variasi aplikasi microsoft power point di kelas IV SD Negeri Bonangrejo. Hal ini dibuktikan dengan peningkatan hasil belajar yang penjabarannya sebagai berikut: Hasil belajar 74.4 pada siklus 1, dan 85 pada siklus 2. Pemanfaatan media dengan media tabel dengan variasi aplikasi microsoft power point lebih efektif untuk menanamkan konsep cara menentukan FPB dan KPK dalam pembelajaran Matematika di kelas IV SD Negeri Bonangrejo semester 1 tahun pelajaran 2015/2016. Dengan menguasai konsep menentukan FPB dan KPK ini peserta didik lebih cepat mampu menyelesaikan soal yang lebih kompleks dalam bentuk soal cerita. 
DAFTAR PUSTAKA

Undang-undang Nomor 20 Tahun 2003 tentang Sistem Pendidikan Nasional.

Peraturan Pemerintah Nomor 19 Tahun 2005 tentang Standar Nasional Pendidikan

Badan Standar Nasional Pendidikan. 2006. Permendiknas RI No. 22 tahun 2006 tentang Standar Isi untuk Satuan Dikdasmen. Jakarta.

Ahmad, M. 1994. Jurnal Pendidikan. Jakarta: Depdikbud.

Arikunto, Suharsimi. 1997. Dasar Evaluasi Pendidikan. Jakarta: Bina Aksara.

B, Simanjutak. 1983. Metodologi Pendidikan. Bandung. Citra Adi Karya.

Depdikbud. 1998. Pedoman Pembuatan dan Penggunaan Alat peragal Media Pembelajaran Sekolah Dasar. Jakarta: Ditektorat sarana Pendidikan Depdikbud.

Depdiknas. 2006. Kurikulum Tingkat Satuan Pendidikan. Jakarta: Depdiknas.

Gafur, Abdul. 1989. Media Pembelajaran. Jakarta.

Hamalik, Oemar. 1994. Media pendidikan. Bandung: Citra Adi Karya.

Handoko, Tri. 2007. Terampil Matematika. Jakarta: Yudhistira.

Heryanto, Nar. 2004. Analisis Hasil Evaluasi. Bandung. Citra Adi Karya.

Huda, Miftahul. 2015. Model-model Pengajaran dan Pembelajaran. Isu-isu Metodis dan Paradigmatis. Yogjakarta: Pustaka Pelajar.

Mudhofir. 1986. Teknologi Instruksional. Bandung: Remaja Rosdakarya.

Mustaqim. Wahib, Abdul. 1990. Psikologi Pendidikan. Jakarta: Rineka Cipta.

Nasution, S. Kurikulum Pembelajaran. Jakarta: Bumi Aksara.

Sadiman, Arief S. 1993. Media Pendidikan. Jakarta: Raja Grafindo Persada

Sudjana, Nana. 1992. Media Pengajaran. Bandung: Sinar Baru.

Sutejo, Bambang. 2008. Aku Siap Aku Bisa 6A. Jakarta: Erlangga.

Syaifudin. 1996. Evaluasi Pendidikan. Bandung. Remaja Rosda Karya.

Syah, Muhibbin, 1997. Psikologi Pendidikan. Bandung: Remaja Rosdakarya

Tim MKDK IKIP Semarang. 1996. Belajar dan pembelajaran. Semarang: IKIP press.

Tim Matematika, 2002. Cerdas Matematika.
Jakarta: Yudhistira. 